\title{
Hypoplasia of the vertebral artery in human - a case report
}

\author{
CAMPOS, D. ${ }^{1,2^{*}}$ \\ ${ }^{1}$ Department of Biology and Pharmacy, Universidade de Santa Cruz do Sul - UNISC, \\ Av. Independência, 2293, CEP 96815-900, Santa Cruz do Sul, RS, Brazil \\ ${ }^{2}$ Department of Basic Health Sciences, Universidade Federal de Ciências da Saúde de Porto Alegre - UFCSPA, \\ Av. Sarmento Leite, 245, CEP 90050-170, Porto Alegre, RS, Brazil \\ *E-mail: dcampos@unisc.br
}

\begin{abstract}
Hypoplasia of the vertebral artery (VA) is rare, and incidentally encountered in radiological imaging techniques. During routine activities in the Laboratory of Human Anatomy from University of Santa Cruz do Sul, Brazil, it was observed a 70 years old male cadaver with hypoplasia of the right VA. Thus, the purpose of this study is to report this case of hypoplasia of the VA emphasizing some morphological, functional and clinical data about this rare vascular abnormality, in order to offer useful information to anatomists, radiologists, vascular and head and neck surgeons. Moreover, to our knowledge, this variation has not been cited in recent medical literature.
\end{abstract}

Keywords: hypoplasia, vertebral artery, cadaver, human.

\section{Introduction}

According to classical descriptions, the vertebral artery (VA) arises from the superior aspect of the subclavian artery, passes through the foramina of all cervical transverse processes except the seventh, curves medially behind the lateral mass of atlas, and then enters the cranium via the foramen magnum. At the lower pontine border, it joins its fellow to form the basilar artery and, occasionally, it may enter the bone at fifth, fourth or seventh cervical transverse foramen (STANDRING, 2008).

This artery is classically divided into 4 segments: the first segment starts from its origin on the subclavian artery to the C6 transverse process; the second from $\mathrm{C} 6$ to $\mathrm{C} 2$ transverse process; third from C2 to the foramen magnum; and the fourth form the foramen magnum to vertebrobasilar junction (TUNCER, AKGÜL and KARABULUT, 2010).

Additionally, the knowledge about the variations of the vertebrobasilar arterial complex is important for surgeons operating at the skull base, craniocervical junction, cervical region and for clinicians interpreting the imaging of this region (SHOJA, TUBBS, KHAKI et al., 2006). Moreover, numerous studies (MIZUTANI, ARUGA, KIRINO et al., 1995; MOKRI, HOUSER, SANDOK et al., 1988; SMITH, SNYDERMAN, KASSAM et al., 2002; MELING, FRIDRICH, EVENSEN et al., 2008; KOCAELI, CHAALALA, ANDALUZ et al., 2009; MATSUSHIMA, KAWASHIMA, MASUOKA et al., 2010; GUPTA, RADHAKRISHNAN, PALIMAR et al., 2013), involving structures of the skull base have described important morphological, functional and clinical data about the VA, including those related to VA hypoplasia (BLICKENSTAFF, WEAVER, YELLIN et al., 1989). Thus, in this study we report an additional rare case of VA hypoplasia emphasizing some aspects of this clinical and morphological vascular unusual configuration.

\section{Case Report}

In a Caucasian adult male cadaver with cause of death by respiratory failure associated with dementia, with 70 years old, belonging to the didactical collection of the Laboratory of Human Anatomy from University of Santa Cruz do Sul, Brazil, it was noted a hypoplasia of the right VA. This abnormal artery had a diameter of $1.50 \mathrm{~mm}$ whereas the left artery a diameter of $6.80 \mathrm{~mm}$. The length of the left VA from its origin to where it entered the foramen transversarium of C6 was $90.10 \mathrm{~mm}$ where as that of the right from its origin to the foramen transversarium of C6 was $75.25 \mathrm{~mm}$. The basilar artery was normal and receives most or all of its blood supply from the contralateral VA (Figure 1). This abnormality was seen only on the right side and there was no sign of deformation in other regions of the encephalic vascular system. The measurements were taken using a digital pachymeter from Digimess ${ }^{\circledR}$, Brazil.

\section{Discussion}

It is known that anomalous blood vessels are commonly reported in the medical literature. These abnormalities may be due to the: choice of unusual paths in the primitive vascular plexus; persistence of vessels normally obliterated; disappearance of vessels normally retained; or incomplete development and to fusions and absorption of parts usually distinct (AREY, 1957).

Shoja, Tubbs, Khaki et al. (2006) reported that bad development and anomalies of the vertebral arteries are also generally considered very rare and have been described in single-case reports and in small series of patients with a single type of pathology.

Some authors estimate that the arteries are unequal in size approximately in $60 \%$ of cases. In this context, the left VA is often larger in size than the right (SHOJA, TUBBS, KHAKI et al., 2006; PATASI, YEUNG, GOODWIN et al., 2009), which is true in our case report. Clinically, it is possible to assume that this may lead to altered hemodynamics and predispose the patient to intracranial aneurysm formation (PATASI, YEUNG, GOODWIN et al., 2009). Therefore, a thorough search for coexisting aneurysms should be undertaken in patients with these anomalies.

Satti, Cerniglia and Koenigsberg (2007) described that endovascular therapy can be performed before these patients 


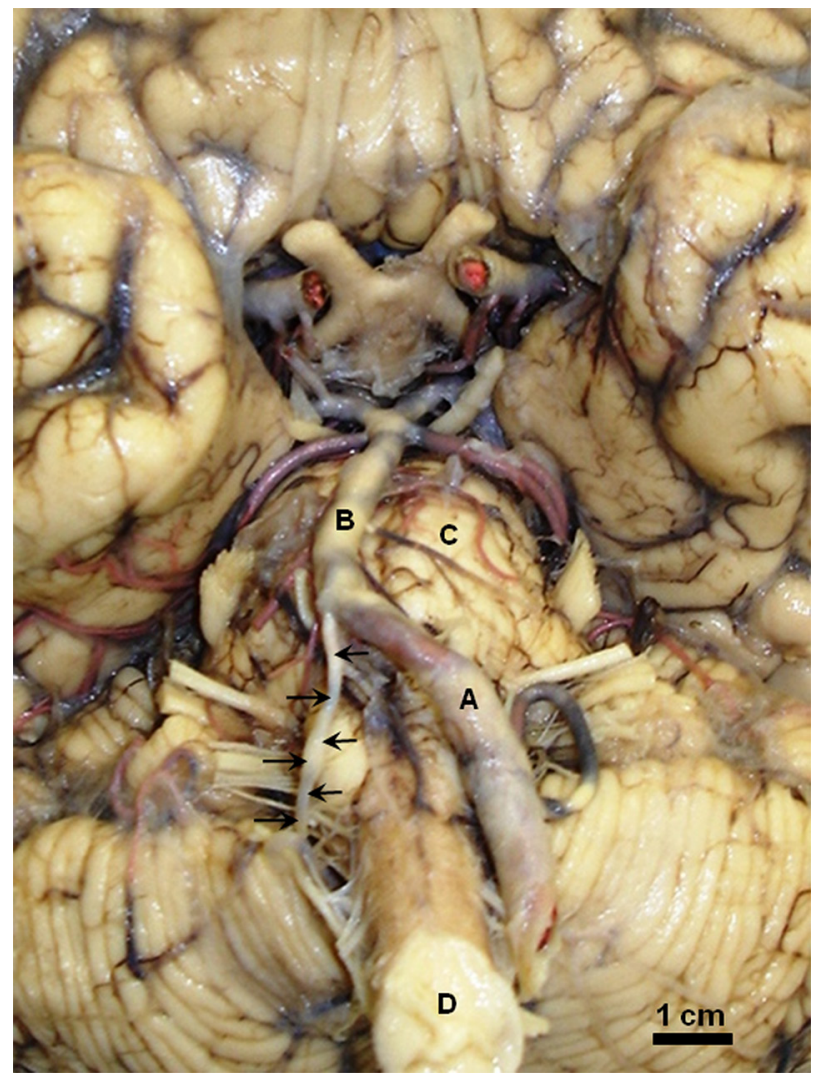

Figure 1. Inferior view of the encephalon showing the hypoplasia of the right vertebral artery (black arrow). Right vertebral artery (A); basilar artery (B); pons (C) and spinal cord (D).

present clinically as subarachnoid hemorrhages or by mass effect, decreasing morbidity and mortality.

According to Blickenstaff, Weaver, Yellin et al. (1989) the incidence of congenital atresia or hypoplasia of the left VA is $3.1 \%$, and of the right VA is $1.8 \%$. There is a clinical description in which was reported bilateral proatlantal arteries with both vertebral arteries absent (WOODCOCK, CLOFT and DION, 2001). In a similar case was reported the absence of cervical segments of both vertebral arteries (HACHEM, ABI KHALIL, SLABA et al., 2008). Another report described the case of a 40 years old woman who presented with a large aneurysm of the left VA in the angiographic absence of a right VA (KAO, TSAI and CHANG, 2003).

Poonam, Singla and Sharma (2010) described that an understanding of the variability of the VA remains most important in angiography and surgical procedures where an incomplete knowledge of anatomy can lead to serious implications. Therewith, this has become more important in the era of carotid artery stents, VA stents and therapeutic options for intercranial interventions.

Dates from the studies (LEMKE, BENNDORF, LIEBIG et al., 1999; SHOJA, TUBBS, KHAKI et al., 2006; SATTI, CERNIGLIA and KOENIGSBERG, 2007) suggested that in angiographic and anatomic postmortem examinations, abnormal VA are incidental findings because they are generally clinically asymptomatic. Also according to these same authors, these abnormalities are of diagnostic importance either prior to vascular surgery in the neck region or in cases of intravascular disease such as: occlusion, thrombosis, arterial dissection, potentially atherosclerosis and arteriovenous malformations or cerebral aneurysms.

In addition, we believe that the neurological disorders (dementia) from the individual reported in our study may be explained, at least in part, by the fact that morphological abnormalities of the VA may favour cerebral disorders because of alterations in cerebral hemodynamics (PATASI, YEUNG, GOODWIN et al., 2009). Thus, other abnormalities in the length and origin of the VA also deserve mention. In this case report we found that left VA had a length greater than the right artery and this was also reported in previous descriptions about the anatomy of the VA (MOORE, DALLEY and AGUR, 2011).

Regarding to the origin, we found that both arteries originate from the first portion of the subclavian artery and entering the sixth cervical foramen. Bergman, Afifi and Miyauchi (2012) showed that the vertebrals enter the sixth cervical foramen in $88 \%$ of cases, seventh in $5 \%$ and fifth in $7 \%$ of cases. It was reported in another study that the artery enters the cervical vertebrae in this proportion: sixth in $94.9 \%$, seventh in $0.3 \%$, fifth in $3.3 \%$ and fourth $1.6 \%$ of cases (HAMILTON, BOYD and MOSSMAN, 1972). Lastly, a classical description reported that the artery enters the foramen transversarium of the sixth cervical vertebra in $90 \%$ of cases, while those of seventh, fifth, fourth, and third in $2 \%, 5 \%, 2 \%$, and $1 \%$ of the cases, respectively (WILLIAMS, WARWICK, DYSON et al., 1995).

In a study that analyzed 500 vertebral arteries, it was observed an abnormal level of entrance into foramen transversarium in $7 \%$ of cases, with a level of entrance into the $\mathrm{C} 3$ in $0.2 \%$, C4 in $1.0 \%$, C5 in $5.0 \%$ and $\mathrm{C} 7$ in $0.8 \%$. In this same study, seventeen abnormalities were right sided and eighteen were left sided (BRUNEAU, CORNELIUS, MARNEFFE et al., 2006).

Finally, regarding to individual variations of the VA, Shoja, Tubbs, Khaki et al. (2006) described that a thorough knowledge of vertebrobasilar variations may improve the outcome of skull base and other head and neck operations and aid in the interpretation of imaging.

Additionally, surgical procedures that would necessitate exposure of VA include: repair of aneurysms, excisions of craniocervical junction masses, vertebral endarterectomy, bypass and bony decompression of the VA. Also anatomical variations in VA if missed can lead to catastrophic sequelae in surgeries like atlantoaxial transarticular screw fixation, anterior cordectomy (SIKKA and JAIN, 2012).

Thus, we undertook this study with the aim of providing a more accurate report about a rare case of VA hypoplasia, because of its interesting relationships with altered hemodynamics and predispose the patient to intracranial aneurysm formation. Moreover, this work aimed to provide a simple but multidisciplinary synthesis of the current knowledge concerning the morphogenesis, variation, and clinical significances of the VA, and to help promoting future studies in this area. Lastly, this study is useful for academics, clinicians and surgeons who handle and have special interest in anatomical structures discussed in this work.

\section{References}

AREY, LB. Developmental Anatomy: a textbook and laboratory manual of embryology. Philadelphia: WB Saunders Company, 1957.

BERGMAN, RA., AFIFI, AF. and MIYAUCHI, R. Vertebral artery variations. In: BERGMAN, RA. Illustrated encyclopedia of human 
anatomic variation. Available from: <http://www.anatomyatlases. org/AnatomicVariants/Cardiovascular/Images0001/0095.shtml>. Acess in: 14 July 2012.

BLICKENSTAFF, KL., WEAVER, FA., YELLIN, AE., STAIN, SC. and FINCK, E. Trends in the management of traumatic vertebral artery injuries. American Journal of Surgery, 1989, vol. 158, n. 2, p. 101-106, discussion 105-106.http://dx.doi.org/10.1016/00029610(89)90355-3 PMid:2757137.

BRUNEAU, M., CORNELIUS, JF., MARNEFFE V, TRIFFAUX $\mathrm{M}$, GEORGE B. Anatomical variations of the V2 segment of the vertebral artery. Neurosurgery, 2006, vol. 59, n. 1, supplement 1, p. S20-S24. PMid:16888547.

GUPTA, C., RADHAKRISHNAN, P., PALIMAR, V., D'SOUZA, AS. and KIRUBA NL. A quantitative analysis of atlas vertebrae and its abnormalities. Journal of Morphological Science, 2013, vol. 30, p. 77-81.

HACHEM, K., ABI KHALIL, S., SLABA, S., JEBARA, V. and GHOSSAIN, M. Non invasive imaging of bilateral vertebral arteries agenesis. Journal des Maladies Vasculaires, 2008, vol. 33, n. 1, p. 2629.http://dx.doi.org/10.1016/j.jmv.2007.12.001 PMid:18313873.

HAMILTON, WJ, BOYD, JD. and MOSSMAN, HW. Human embryology: prenatal development of form and function. 4 th ed. London: The Macmillan Press, 1972.

KAO, CL., TSAI, KT. and CHANG, JP. Large extracranial vertebral aneurysm with absent contralateral vertebral artery. Texas Heart Institute Journal, 2003, vol. 30, n. 2, p. 134-136. PMid:12809256.

KOCAELI, H., CHAALALA, C., ANDALUZ, N. and ZUCCARELLO, M. Spontaneous intradural vertebral artery dissection: a single-center experience and review of the literature. Skull Base, 2009, vol. 19, n. 3, p. 209-218.http://dx.doi.org/10.1055/s-0028-1114296 PMid:19881901.

LEMKE, AJ., BENNDORF, G., LIEBIG, T. and FELIX, R. Anomalous origin of the right vertebral artery: review of the literature and case report of right vertebral artery origin distal to the left subclavian artery. American Journal of Neuroradiology, 1999, vol. 20, n. 7, p. 1318-1321. PMid:10472992.

MATSUSHIMA, T., KAWASHIMA, M., MASUOKA, J., MINETA, T. and INOUE, T. Transcondylar fossa (supracondylar transjugular tubercle) approach: anatomic basis for the approach, surgical procedures, and surgical experience. Skull Base, 2010, vol. 20, n. 2, p. 83-91. http://dx.doi.org/10.1055/s-0029-1242193 PMid:20808532.

MELING, TR., FRIDRICH, K., EVENSEN, JF. and NEDREGAARD, B. Malignant granular cell tumor of the skull base. Skull Base, 2008, vol. 18, n. 1, p. 59-66.http://dx.doi.org/10.1055/s-2007-992763 PMid:18592017.

MIZUTANI, T., ARUGA, T., KIRINO, T., MIKI, Y., SAITO, I. and TSUCHIDA, T. Recurrent subarachnoid hemorrhage from untreated ruptured vertebrobasilar dissecting aneurysms. Neurosurgery, 1995, vol. 36, n. 5, p. 905-911, discussion 912-913.http://dx.doi. org/10.1227/00006123-199505000-00003 PMid:7791980.

MOKRI, B., HOUSER, OW., SANDOK, BA. and PIEPGRAS, DG. Spontaneous dissections of the vertebral arteries. Neurology, 1988, vol. 38, n. 6, p. 880-885.http://dx.doi.org/10.1212/WNL.38.6.880 PMid:3368069.

MOORE, KL., DALLEY, AF. and AGUR, AMR. Anatomia orientada para a clínica. 6th ed. Rio de Janeiro: Guanabara Koogan, 2011.

PATASI, B., YEUNG, A., GOODWIN, S. and JALALI, A. Anatomic variation of the origin of the left vertebral artery. International Journal of Anatomical Variations, 2009, vol. 2, p. 83-85.

POONAM, SINGLA, RK. and SHARMA, T. Incidence of anomalous origins of vertebral artery-anatomical study and clinical significance. JCDR, 2010, vol. 4, p. 2626-2631.

SATTI, SR., CERNIGLIA, CA. and KOENIGSBERG, RA. Cervical vertebral artery variations: an anatomic study. American Journal of Neuroradiology, 2007, vol. 28, n. 5, p. 976-980. PMid:17494682.

SHOJA, MM., TUBBS, RS., KHAKI, AA., SHOKOUHI, G., FARAHANI, RM. A rare variation of the vertebral artery. Folia Morphologica, 2006, vol. 65, n. 2, p. 167-170. PMid:16773609.

SIKKA, A. and JAIN, A. Bilateral variation in the origin and course of the vertebral artery. Anatomy Research International, 2012, vol. 2012, p. 580765. http://dx.doi.org/10.1155/2012/580765. PMid:22720161.

SMITH, JC., SNYDERMAN, CH., KASSAM, AB. and FUKUI, MB. Giant parapharyngeal space lipoma: case report and surgical approach. Skull Base, 2002, vol. 12, n. 4, p. 215-220. PMid:17167686.

STANDRING, S. Gray's Anatomy: the anatomical basis of clinical practice. 40th ed. Edinburgh: Churchill Livingstone/Elsevier, 2008.

TUNCER, MC., AKGÜL, YH. and KARABULUT, O. Angiography imaging of absence vertebral artery causing of pulsatile tinnitus: a case report. International Journal of Morphology, 2010, vol. 28, p. 357-363.

WILLIAMS, PL., WARWICK R, DYSON, M. and BANNISTER, LH. Gray anatomia. 37th ed. Rio de Janeiro: Guanabara Koogan, 1995.

WOODCOCK, RJ., CLOFT, HJ. and DION, JE. Bilateral type 1 proatlantal arteries with absence of vertebral arteries. American Journal of Neuroradiology, 2001, vol. 22, n. 2, p. 418-420. PMid:11156793.

Received July 31, 2014 Accepted November 15, 2015 